\title{
Fostering Niches among SMEs in Malaysia through Organizational Commitment, Leadership, Organizational Culture and Job Satisfaction
}

\author{
Cristina G. Gallato ${ }^{1}$, Safiah Rashid ${ }^{2}$, Ruswiati Suryasaputra ${ }^{1}$, Ari Warokka ${ }^{1}$, \\ Kristy Aireen G. Reamillo ${ }^{3}$ and Haim Hilman bin Abdullah ${ }^{1}$ \\ ${ }^{1}$ Universiti Utara Malaysia, Malaysia, OYAGSB \\ ${ }^{2}$ Universiti Tun Abdul Razak, Pintar Campus, Malaysia \\ ${ }^{3}$ St. Paul University, Quezon City, Philippines
}

\begin{abstract}
Niche creation is a challenge among firms regardless of size, ownership and the kind of product/service they offer. Once it is created, fostering such niche becomes a greater issue. In this paper, we focused on the SMEs in emerging markets particularly in Malaysia. By using questionnaires, data was gathered from 100 employees working in SMEs particularly in Selangor, Malaysia. The purpose of this study is to let owners/managers/founders of SMEs better understand how fostering niches is influenced by organizational commitment, leadership, and organizational culture, towards job satisfaction as antecedents of competitive advantage and/or success of SMEs. Employees' attitudes and behaviours are affected by the relationship between them and their employer. This relationship is referred to as organizational commitment.

Moreover, leadership and organizational culture considerably have an influence on job satisfaction. Understanding this concept will aid employers to instil strong organizational culture and create solid organizational commitment among their employees and lead effectively so that they would be able to retain their well-experienced and skilful employees. Ultimately job satisfaction plays a very important role in the success of organizations particularly in the context of SMEs in Malaysia. The findings revealed positive relationships among the variables and their importance as determinants of job satisfaction in SMEs, which hopefully could contribute to the extant literature on job satisfaction and competitive advantage from the perspective of this country in Asia.
\end{abstract}

Keywords: Organizational Commitment, Leadership, Organizational Culture, Job Satisfaction, SMEs niche.

\section{Introduction}

The effects brought about by globalization, market liberalization and technological change have posed threats and challenges to organizations in the world. Malaysia, which is fast moving towards being a New Industrialized Country (NIC) is not an exception. Such threats and challenges put these organizations in unfavourable positions which evidently could affect their survival regardless of size, owners, managers, types of businesses, or even their respective environment. This situation has also affected the small and medium enterprises (SMEs) in general as these external factors are beyond their control. Nevertheless, SMEs can control 
their internal environment which can help them to fully exploit their strengths and minimize their weaknesses. This ability lies more on the owners and/or managers. This notion is supported by recent organizational crises that have emphasized the need for effective leadership, better working environment and personal commitment from organizational decision makers which become more critical for organizational success (Earle, 1996). The ability of the owner and/or manager to provide better working environment, effective leadership, positive organizational culture, and stronger commitment towards the firm will lead to greater employees' job satisfaction. Hence, organizational commitment and leadership, organizational culture along with their effect on job satisfaction are some of the crucial elements in determining the niches or competitive advantage and success of organizations.

On the other hand, the inability to create and provide positive and supportive working environment will result in talented, well-experienced and skilled employees leaving for a better workplace. Hence, a strong organizational culture is required, effective leadership is desired, and a solid organizational commitment is needed to retain these employees. A stronger organizational culture allows employees toward realizing greater job satisfaction, which should ultimately lead to increased productivity, commitment, and success to the organization (Bellou, 2010; Eskildsen, Kristensen, and Antvor, 2010). Similarly, effective leadership of a manager can result in higher employee job satisfaction (Rad and Yarmohammadian, 2006; Yiing and Ahmad, 2009). On the other hand, organizational commitment can result in employee loyalty to the organization, which apparently is important because of the need to retain a strong workforce (Pool and Pool, 2007; Yousef, 2001).

\section{Research Problem}

Ahmad and Seet (2009) mentioned that there are no comprehensive studies or statistics on the failure rate of SMEs in
Malaysia. However, they reported that based on a Portal Komuniti KTAK (2006), the rate is claimed to be about 60 percent. Considering this high failure rate among SMEs in Malaysia, clearly it is important to identify the causes of failure.

The high failure rate has implications not only on the national economic growth and employment rate but also on the wealth and health of the owner and/or manager of the business. Several studies on the reasons for business failure of SMEs found that managerial ineffectiveness is obvious in the area of human resource management and general management, which is among the top five problems (Huang and Brown, 1999; Sadler-Smith, Hamson, and Chaston, 2003). The managerial ineffectiveness has the potential to influence employee's job satisfaction. Their decisions to continue to be a part of the firm owe to a large degree on their job satisfaction level which among others is influenced by their perceptions towards leadership, culture and commitment developed within the organization. Employee's job satisfaction is important to an organization because it determines the quality of work and the attitudes that employees have towards their works, which ultimately assures the survival of the business (Wright, 2006) and would aid in attaining competitive advantage.

\section{Objectives of the Study}

The purpose of this paper is to better understand the relationships between organizational commitment, leadership, organizational culture, and job satisfaction of SMEs in Malaysia. Cole and Bruch (2006) stated that the relationship between employees and organizations influence their attitudes and behaviours. This relationship is referred to as organizational commitment. Robbins (1996) indicates that leadership and organizational culture considerably have an influence on several outcomes including job satisfaction.

Several studies have been conducted on organizational culture, leadership, organizational commitment, and job satisfaction. Despite the increased attention given to these variables some 
issues still require further investigation due to limited study on these areas in the local context especially in relation to SMEs in Malaysia. As such, the other purpose of this study is to examine whether the findings in the local context is similar or different from other contexts. Of the studies conducted on SMEs in Malaysia, the emphasis is generally on general profile of the SMEs, personal attributes of the owners, constraints faced by them and the effectiveness of the assistance programmes provided for them by various government agencies. In view of the importance of SMEs to the economy in general, more focused research needs to be carried out. One such area of interest of this study is to investigate the influence of SMEs organizational factors namely organizational commitment, leadership, and organizational culture on employee's job satisfaction and towards competitive advantage or organizational success.

\section{The Nature and Importance of SMEs in Malaysia}

In Malaysia, definitions of SMEs are based on the sector and number of employees and/or annual sales turnover (National SME Development Council or NSDC, 2008). SMEs are divided into micro, small and medium sized enterprises respectively.

The importance of SMEs to the economy has been documented in many studies (Ahmad and Seet, 2009; Desouza and Awazu, 2006; Oke, Burke, and Myers, 2007; O'Regan and Ghobadiah, 2004). Like in other countries, SMEs in Malaysia are also considered as a vital component of the national economy. It accounts for 99.2 per cent or 518, 966 of all businesses and thus forms the backbone of industrial growth (Business Times, 2010). Similarly, their contribution to gross domestic product (GDP) has increased from 29.4 per cent in 2005 to 32 per cent in 2008 (SME Corp, 2010) and has increased further to 37 per cent in 2010. In terms of their contribution to employment and total exports, the contribution has also showed an increasing trend from 56 per cent in 2005 to 57 per cent in 2010. This contribution to Malaysia total exports is equivalent to 19 per cent of
Malaysia in 2009 (NSDC, SME Annual Report 2009/10).

\section{Organizational Commitment}

Job satisfaction and organizational commitment are two of the most prominent work attitudes examined in the work and organizational literature. Organizational commitment (Meyer and Allen, 1997) is "a psychological state that characterizes the employee's relationships with the organization; and has implications for the decision to continue membership in the organization" (p.67). Other researchers use similar definitions that refer to organizational commitment as an employee's attachment, goal congruency, identification, loyalty and allegiance to their organization.

When employees are dissatisfied at work, they are less committed and will look for other opportunities to quit. If opportunities are unavailable, they may emotionally or mentally "withdraw" from the organization. Many studies across different industries and geographical regions revealed strong correlations between organizational commitment with job satisfaction (Caykoylu, Egri, and Havlovic, 2007; Chen, 2007; Jernigan, Beggs, and Kohut, 2002; Leong, 1996; Lok and Crawford, 2004).

\section{Leadership}

Leadership is one of the most relevant aspects of ensuring effectiveness in organizations and in managing change. It is often considered as the base for organizational performance and growth. The importance of leaders' role in influencing employees' behaviour have been shown by previous studies (Asgari, Silong, Ahmad and Samah, 2008; Bhal, Gulati and Ansari, 2009). Leadership style has been investigated for its relationship with various organizational variables such as locus of control (Chen and Silverthorne, 2008), innovative work behaviour (Lee, 2008) and many more. Other study by Liu, Fellow, and Fang, (2003) found transformational leadership to be positively correlated with the improvement of subordinates' working environment, the 
satisfaction of demands and executed performance.

\section{Organizational Culture}

Cultural background is found to have a profound impact on job satisfaction (Testa and Mueller, 2009). They reported that the level of job satisfaction of employees from countries where the culture is more traditional is greater than employees from countries where the culture is more egalitarian. Previous studies on the relationship between those variables were conducted in countries such as Turkey, Egypt, the United States and Europe where the culture is entirely different from Malaysia. Furthermore, those studies were also focused on big firms such as manufacturing firms, learning organizations, R\&D organizations, hospitals, schools and universities but less on SMEs.

The notion of "culture" is often associated with exotic, distant peoples and places, with myths, rites, foreign languages and practices (Lund, 2003). To the organization, culture represents the organization personality. Many times organizational culture is simply formed in an organization without any sort of training or coaching; it is formed when a group has worked together for a certain amount of years and over the time it became the standard practice and norms of that organization. There seem to be a wide agreement that organizational culture refers to a system of shared meaning held by members that distinguishes the organization from other organization (Robbins \& Judge, 2009).

\section{Job Satisfaction}

Job satisfaction is the most frequently studied variable in organizational research (Blau, 1999). The intense concentration of research on job satisfaction is due to the fact that it affects employees and organizations. Job satisfaction denotes an employee's subjective assessment of his or her job (Donohue and Heywood, 2004).
Robbins and Judge (2009) defined job satisfaction as a collection of feelings that an individual holds towards his or her job. Sources of low satisfaction are associated with working with unskilled or inappropriately trained staff, laborious tasks such as documentation, repetition of duties, tensions within role expectations, role ambiguity, role conflict, job/patient care, feeling overloaded, the increasing need to be available for overtime, relations with co-workers, personal factors and organizational factors (Rad and Yarmohammadian, 2006).

\section{Conceptual Framework}

Previous studies conducted on job satisfaction examined the concept as an independent variable (Lok and Crawford, 2004; Yiing and Ahmad, 2009; Yousef, 2001). It is because job satisfaction is treated as the outcome of the other independent variables such as leadership style, organizational commitment and organizational culture. On the other hand, previous studies on organizational culture examined this variable as either the independent variable (Lok and Crawford, 2004, 1999; Eskildsen, Kristensen, and Antvor, 2010) or moderating variable (Yiing and Ahmad, 2009).

This study treated organizational culture as an independent variable so that comparison between studies could be done (Bellou, 2010; Lok and Crawford, 2004; Lund, 2003). There are prior studies examined where leadership is an independent variable (Lok and Crawford, 2004; Yiing and Ahmad, 2010; Yousef, 2000). This is because the variable is the antecedent of job satisfaction. For the variable organizational commitment some of previous studies investigated considered it as the independent variable ( Lok and Crawford, 2004; Yousef, 2001), some as the dependent variable (Lee, 2008) and a few as the moderating or mediating variable (Yousef, 2001). Therefore, the theoretical framework of this study is as shown in Figure 1. 


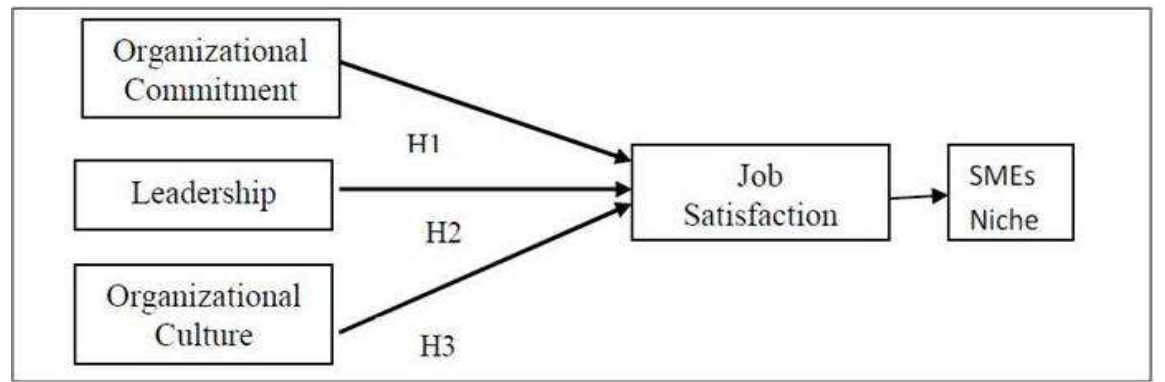

Figure 1: Theoretical Framework

\section{Hypotheses}

These research structures are mainly framed by the organization behaviour mode as proposed by Robbins (1996), which indicates that leadership, organizational culture, and organizational commitment substantially cause influence on output of personnel resources such as job satisfaction. Organizational commitment, leadership, and organizational culture are the three variables that are believed to influence the level of employees' job satisfaction.

The commitment of the people in the organization is also essential to ensure the successful implementation of the organizational policies and plans. It is ensuring the necessary level of commitment among employees or managers are unequivocally important so as to ensure successful implementation of the organizational strategies and plans of actions (Rashid, Sambasivan, and Johari, 2003). Studies on the relationship between organizational commitment and job satisfaction have shown that correlation exists between organizational commitment with job satisfaction (Caykoylu, Egri and Havlovic, 2007; Chen, 2007). Hence, the hypothesis proposed and tested are as follows:

H1: There is a significant relationship between organizational commitment and job satisfaction.

For the second variable that is leadership, Rad and Yarmohammadian (2006) and Yiing and Ahmad (2009) suggested a significant correlation between the use of leadership behaviours and job satisfaction of employees. Hence, the second hypothesis is as follows:

H2: There is a significant relationship between leadership and job satisfaction.

Organizational culture influences job satisfaction. For instance, Sempane, Rieger, and Roodt, (2002) find organizational cultural values of respect for people, innovation, stability and aggressiveness have strong association with job satisfaction, information sharing and affective commitment. The findings by previous studies confirmed of the significant relationship between organizational culture and job satisfaction (Lund, 2003; Sempane, Rieger, and Roodt, 2002). As such, the following hypothesis is as follows:

H3: There is a significant relationship between organizational culture and job satisfaction.

\section{Methodology}

The main objective is to investigate the relationships between organizational commitment, leadership and organizational culture to job satisfaction in the context of SMEs in Malaysia. The present research setting to test the framework in Figure 1 consisted of employer-employee relationships in Malaysia.

\section{Survey}

We conducted a survey of employees working in the SMEs in Selangor, Malaysia. The survey is cross-sectional and its unit of analysis is individual employee. These 
enterprises are located in Selangor, specifically in the area of Shah Alam, Puchong, and Rawang. We picked these locations since Selangor has the largest number of SMEs. The category of business selected is manufacturing, manufacturingrelated services and agro-based industries category. We based the selection on the size of the business according to the definition of SMEs given by NSDC. The permission to conduct the study and list of the respondents were obtained and gathered from the owners of those SMEs who were contacted by telephone and personal visits.

We distributed one hundred forty (140) self-administered questionnaires to collect data in order to examine the preceding issues because: (1) responses could be easily quantified and summarized, (2) data could be collected quickly, inexpensively and efficiently, and (3) a large number of participants could be reached in a short span of time. The respondent was given three days to complete the questionnaires. There were two versions of questionnaires available. The first version is in English and the second one is in Bahasa Melayu. Considering that most of the respondents have little understanding of English, all measures were translated into Bahasa Melayu. The process included two steps. First, several English lecturers who were fluent both in Bahasa Melayu and English were asked to translate the items in the questionnaires to Bahasa Melayu. Next, the Bahasa Melayu version was given to independent translators who were not aware of the English version and were asked to translate back to English.

The questionnaires have several sections: Job Satisfaction items, Leadership items,
Organizational Culture items, Organizational Commitment items and some demographic details. The completion time for the instruments was approximately 30 minutes. After day three, we went to collect the completed questionnaires and after eliminating questionnaires with excessive amounts of missing data, only 100 questionnaires were useable. This gives a response rate of 71 per cent. This high response rate is mainly due to several follow ups with a reminder to those that have not yet responded and use of incentives to ensure participation.

All questionnaire items scored on sevenpoint Likert scale for uniformity in measuring the variables except the demographic variables.

\section{Data Screening and Analysis}

Several data screening procedures were carried out for this study: Missing Value, Outliers, Reliability Test, and Normality Test. Several analyses were also performed: Correlation Analyses, Factor Analyses, Independent-sample t-Test, Oneway ANOVA, and Simple Regression Analyses. The results of the analyses are discussed in the next section.

The 100 dataset were coded and saved into SPSS Version 14.0. Data screening for missing values was carried out and no missing value was detected. Thus, the treatment for missing values is not needed. The procedure for outliers was also performed, no dataset was deleted because the Mahalanobis Distance cut off point $(\mathrm{df}=$ 17 at $p=0.001$ ) is 40.79 which is more than the maximum value of 31.82 .

Table 1: Reliability Test Result

\begin{tabular}{|l|l|}
\hline & Cronbach's Alpha \\
\hline Leadership & 0.644 \\
\hline Organizational Culture & 0.796 \\
\hline Organizational Commitment & 0.835 \\
\hline
\end{tabular}

The reliability test is to assess the accurateness and preciseness of the measurement made on a certain variable by a research instrument. The output of the test as shown in Table 1 indicates that the alpha coefficient (Cronbach's Alpha) for 
organizational commitment items is 0.835 , for leadership items is 0.644 , and for organizational culture items is 0.896, indicating that the items have relatively high internal consistency.

Data screening for normality was also carried out. Normality tests are used to determine whether a data set is wellmodelled by a normal distribution or not, or to compute how likely an underlying random variable is to be normally distributed. All items of the four constructs were transformed to $\mathrm{z}$-score. Items that have $z$-score value $>2$, was transformed to t-score, and finally transformed back to zscore (zt-score).

$\begin{array}{ll}\begin{array}{l}\text { Relationships } \\ \text { Commitment, } \\ \text { Organizational } \\ \text { Satisfaction }\end{array} & \text { Culture, arganizational } \\ \text { Leadership, } \\ \text { and Job }\end{array}$

Several analyses were performed including Correlation Analyses, Factor Analyses, Independent-sample t-Test, One-way ANOVA, and Simple Regression Analyses. Correlation Analyses are a measurement about the strength of the linear relationship between two variables (correlation coefficient). For the study, the correlation coefficients between two variables were analyzed. Table 2 shows the Variable Correlations Coefficient.

Table 2: Variable Correlations Coefficient

\begin{tabular}{|l|l|l|l|}
\hline & 1 & 2 & 3 \\
\hline 1. LS & $0.532^{* *}$ & & \\
\hline 2. OC & & & \\
\hline 3. CO & $0.819^{* *}$ & $0.769^{* *}$ & \\
\hline \multicolumn{4}{|c|}{ Note: ${ }^{*} \mathrm{p}<0.05,{ }^{* *} \mathrm{p}<0.01$} \\
\end{tabular}

Description of variables: LS - Leadership, OC - Organizational culture, CO - Organizational Commitment

The results showed that there is a positive correlation between leadership and organizational culture $(\mathrm{r}=0.532$ at $\mathrm{p}<0.01)$; between organizational commitment and organizational culture $(\mathrm{r}=0.819$ at $\mathrm{p}<0.01)$. Therefore, it can be concluded that there is a strong association between organizational commitment and leadership. Conversely, there is a weak association between leadership and organizational culture.

The dataset has also been analysed to determine the extent to which underlying, unmeasured issues, or factors, influence a set of related measures, or variables. Hence, factor analysis was performed for the independent variables namely organizational culture, leadership and organizational commitment. The output of the factor analyses showed that there are four components however the independent variables of the study are only three. Therefore, the item with the lowest value was deleted.

First item deleted was OC1 (organizational culture item one) with extraction value of 0.301 , which has the lowest value. Then, the factor analysis was run again, but it still giving four components. By referring again to the Communalities table, item with the lowest item, which was OC2 (organizational culture item two) with extraction value of 0.584 has been identified and deleted. The last analysis finally showed only three components.

Table 3: Total Variance Explained

\begin{tabular}{|l|l|l|}
\hline \multirow{2}{*}{ Component } & Extraction sums of Squared Loadings \\
\cline { 2 - 3 } & Total & \% of Variance \\
\hline 1 & 2.130 & 23.669 \\
\hline 2 & 4.012 & 44.578 \\
\hline 3 & 1.336 & 14.843 \\
\hline \multicolumn{2}{|c|}{ Note: $d f=6$, Sig. 0.000} \\
\hline
\end{tabular}


As illustrated in Table 3, the Eigen values in the Total Variance Explained table exhibited that the factor loading of the first three factors are 4.012, 2.130, and 1.336 respectively, which confirmed of the three components. According to Hair et al. (2010), in a sample of 100 respondents, factor loadings of 0.55 and above are significant.

Table 4 shows the Kaiser_Meyer_Olkin of Sampling Adequacy (KMO) values for the three independent variables of this study. The KMO indicated that the degree of common variance in the dataset for organizational commitment is mediocre $(\mathrm{KMO}=0.607)$ and miserable for both leadership (KMO = 0.513) and organizational culture $(\mathrm{KMO}=0.500)$. The KMO values for organizational commitment suggested that the factors extracted account for a fair amount of variance but not a substantial amount. On the other hand, the KMO values for leadership and organizational culture suggested the factors extracted account for little amount of variance.

Table 4: KMO Values

\begin{tabular}{|l|l|l|}
\hline Variables & $\begin{array}{l}\text { Kaiser-Meyer-Olkin } \\
\text { (KMO) }\end{array}$ & $\begin{array}{l}\text { Degree of Common } \\
\text { Variance }\end{array}$ \\
\hline Leadership & 0.513 & Miserable \\
\hline Organizational Commitment & 0.607 & Mediocre \\
\hline Organizational Culture & 0.500 & Miserable \\
\hline
\end{tabular}

\section{Regression Analysis}

This analysis is a set of statistical procedures used to predict and explain the value of dependent variable based on the value of one or more independent variable(s). In this case, the analyses were used to predict and explain the value of job satisfaction based on the value of three independent variables namely, organizational commitment, leadership and organizational culture.

Table 5 showed that the Pearson correlation value between organizational culture and job satisfaction is 0.959 at pvalue $=0.000$, which indicated that there is a relationship between organizational culture and job satisfaction. In addition, the Pearson correlation value between leadership style and job satisfaction is 0.632 at $p$-value $=0.000$, which indicated that there is a relationship between leadership style and job satisfaction. Finally, the correlation between organizational commitment and job satisfaction is 0.885 at $p$-value $=0.000$, which indicated that there is a relationship between organizational commitment and job satisfaction.

Table 5: Regression Analysis - Correlations

\begin{tabular}{|l|l|l|}
\hline & Job Satisfaction \\
\hline & Pearson Correlation & Sig. \\
\hline Leadership & 0.632 & 0.000 \\
\hline Organizational Culture & 0.959 & 0.000 \\
\hline Organizational Commitment & 0.885 & 0.000 \\
\hline
\end{tabular}

Table 6 shows that there is a significant positive relationship between organizational commitment and job satisfaction, where t-value is more than 1.96 with $\beta=0.247$ at $p$-value lower than 0.05. Therefore, H3 is accepted.
There is a significant positive relationship between organizational culture and job satisfaction, where t-value is more than 1.96 with $\beta=0.726$ at $p$-value lower than 0.05 , therefore, $\mathrm{H} 1$ is accepted. 
However, there is no significant positive relationship between leadership and job satisfaction, where t-value is less than 1.96 with $\beta=0.0566$ at $p$-value more than 0.05 , therefore, $\mathrm{H} 2$ is rejected.

Table 6: Regression Analysis - Coefficients

\begin{tabular}{|c|c|c|c|c|c|}
\hline & \multicolumn{2}{|c|}{$\begin{array}{l}\text { Unstandardized } \\
\text { Coefficients }\end{array}$} & $\begin{array}{l}\text { Standardized } \\
\text { Coefficients }\end{array}$ & \multirow[t]{2}{*}{$t$} & \multirow[t]{2}{*}{ Sig. } \\
\hline & B & Std. Error & Beta & & \\
\hline Leadership & 0.053 & 0.035 & 0.056 & 1.517 & 0.133 \\
\hline Organizational Culture & 0.719 & 0.041 & 0.726 & 17.699 & 0.000 \\
\hline Organizational Commitment & 0.238 & 0.052 & 0.247 & 4.550 & 0.000 \\
\hline
\end{tabular}

In summary, several determinants of job satisfaction were evaluated so as to investigate the relationships between organizational commitment, leadership, organizational culture and job satisfaction.

First, organizational commitment was found to be related with job satisfaction, which supports H1. This finding is consistent with the findings of Lok and Crawford (2004) but contrary to the findings of Lee and Mowday (1989). It is recommended that attention be given by the owners and/or managers to these two variables in order for employees to have job satisfaction for a better cause to the organization such as higher customer satisfaction, higher productivity, and higher financial achievement.

Second, leadership is related to job satisfaction. H2 stated that there is a significant relationship between leadership and job satisfaction. In this study however, leadership variable was found not having positive correlation with job satisfaction. This is contrary to the findings of Yousef (2001) and Rad and Yarmohammadian (2006) probably because different occupational groups possibly may have different determinants of job satisfaction.

H3 stated that there is a significant relationship between organizational culture and job satisfaction. Several insights come to the fore from the results of this study, like, organizational culture was positively correlated with job satisfaction. This finding supported the third research hypothesis and is consistent with the studies of Bellou (2010), Testa and Mueller (2009), Lund (2003), and Lok and
Crawford (2004). These findings can be incorporated by employers/owners by shaping organizational culture to enhance the overall level of job satisfaction of their employees. This way, the organization can minimize the chances of losing talented individuals and thus is more likely to create a competitive advantage

\section{Implications}

There can be a number of possible implications for the owners and/or managers of Malaysian SMEs from this study. SMEs owners and/or managers need to realize the impact of organizational commitment and culture as well as leadership upon their employees' job satisfaction in the workplace because needless to say, employees are the most important assets in organizations.

Organizational commitment defines how strong the individual's beliefs are toward the organization and its goal. The outcomes of this study imply that SMEs owners and/or managers can increase the level of employees' job satisfaction in the organization by increasing employees' perceived commitment towards the organization. A positive, satisfying work environment increases employee's desire to stay with the organization. Commitment enables employees to collaborate and solve work problems together as a successful team, because they value commitment.

Owners and/or managers, through their actions, help to create the proper environment for their employees to be motivated, thereby would result in high job satisfaction which, in turn, can contribute 
to higher productivity, gain competitive advantage, and eventually gain success. The results of this study suggest that SMEs owners and/or managers can increase the level of employees' job satisfaction through a strong organizational culture. This may be due to the fact that an organization's culture provides a sense of identity to its members. The clearer an organization's shared perception and values are defined, the stronger people can associate themselves with their organization's mission and feel a vital part of it.

\section{Limitations of the Study and Suggestions for Future Research}

There are certain limitations of this study. First, the data rely on self-report and survey data. This runs the risk of response bias as respondents report what they think the researcher is looking for rather than what they think or feel. Second, we measured the variables at a single point in time. We acknowledge that the variables examined in this study are to be developed over time. Therefore, a longitudinal study would be needed. Third, we have only investigated a direct relationship between variables; organizational culture, leadership, organizational commitment, and job satisfaction. We further acknowledge that the organizational environment is complex; hence there are other variables that might mediate or moderate the relationship between the investigated variables which might alter the findings of the study. Moreover, only ten SMEs in Selangor, Malaysia were involved. This factor limits the possibility of generalizing from the study findings. Therefore, the findings should be interpreted with caution since the respondents do not represent all SMEs in Malaysia. Hence, future study in this area should involve a larger number of participants and across various industries in the context of SMEs to provide for replication and better generalization. In addition, future research should identify and assess the effects of moderating variables or mediating variables to the above relationship.

\section{References}

Ahmad, H. N. \& Seet, P.- S. (2009). "Dissecting Behaviours Associated with Business Failure: A Qualitative Study of SME Owners in Malaysia and Australia," Asian Social Science, 5(9), 98 - 104.

Asgari, A., Silong, A. D., Ahmad, A. \& Samah, B. A. (2008). "The Relationship Between Leader-Member Exchange, Organizational Inflexibility, Perceived Organizational Support, Interactional Justice and Organizational Citizenship Behaviour," African Journal of Business Management, 2(8), 138 - 145.

Bellou, V. (2010). "Organizational Culture as a Predictor of Job Satisfaction: The Role of Gender and Age," Career Development International, 15(1), 4 - 19.

Bhal, K. T., Gulati, N. \& Ansari, M. A. (2009). "Leader-Member Exchange and Subordinate Outcomes: Test of a Mediation Model," Leadership \& Organizational Development Journal, 30(2), 106 - 125.

Blau, G. (1999). "Testing the Longitudinal Impact of Work Variables and Performance Appraisal Satisfaction on Subsequent Overall Job Satisfaction," Human Relations, 52(8), 1099 - 1113.

Caykoylu, S., Egri, C. P. \& Havlovic, S. (2007). 'Organizational Commitment Across Different Employee Groups,' The Business Review, Cambridge, 8(1), 191-197.

Chen, J.- C. \& Silverthorne, C. (2008). "The Impact of Locus of Control on Job Stress, Job Performance and Job Satisfaction in Taiwan," Leadership and Organization Development Journal, 29(7), 572 - 582.

Chen, Y. J. (2007). 'Relationships among Service Orientation, Job Satisfaction, and Organizational Commitment in the International Tourist Hotel Industry,' Journal of American Academy of Business, Cambridge, 11(2), 71-82. 
Cole, M. S. \& Bruch, H. (2006). "Organizational Identity Strength, Identification, Identification, and Commitment and Their Relationship with Turnover Intention: Does Organizational Hierarchy Matter?," Journal of Organizational Behaviour, 27, 585 - 605.

Deal, T. E. \& Kennedy, A. A. (1982). 'Corporate Cultures: The Rites and Rituals of Corporate Life,' Harmondsworth: Penguin Books.

Desouza, K. C. \& Awazu, Y. (2006). "Knowledge Management at Smes: Five Peculiarities," Journal of Knowledge Management, 10(1), 32 - 43.

Donohue, S. M. \& Heywood, J. S. (2004). "Job Satisfaction and Gender: An Expanded Specification from the NLSY," International Journal of Manpower, 25(2), 211 - 234.

Earle, V. (1996). 'Motivational Leadership: Effective leadership requires perception and caring,' Executive Excellence, 3(11), 1617.

Eskildsen, J., Kristensen, K. \& Antvor, H. G. (2010). "The Relationship between Job Satisfaction and National Culture," The TQM Journal, 22(4), 369 - 378.

Huang, Z. \& Brown, A. (1999). "An Analysis and Classification of Problems in Small Business," International Small Business Journal, 18(1), 73 - 85.

Jernigan, I. E., Beggs, J. M. \& Kohut, G. F. (2002). "Dimensions of Work Satisfaction as Predictors of Commitment Type," Journal of Managerial Psychology, 17(7), 564-579.

Lee, J. (2008). "Effects of Leadership and Leader-Member Exchange on Innovativeness," Journal of Managerial Psychology, 23(6), 670 - 687.

Lee, T. W. \& Mowday, R. T. (1987). "Voluntarily Leaving an Organization: An Empirical Investigation of Steers and Mowday's Model of Turnover," Academy of Management Journal, 30, 721 - 743.
Leong, C. S., Furnham, A. \& Cooper, C. L. (1996). "The Moderating Effect of Organizational Commitment on the Occupational Stress Outcome Relationship," Human Relations, 49(10), 1345-1363.

Liu, A., Fellow, R. F. \& Fang, Z. (2003). "The Power Paradigm of Project Leadership," Construction Management and Economics, 21(8), 819 - 829.

Li, Y. C. (2004). 'Examining the Effect of Organization Culture and Leadership Behaviors on Organizational Commitment, Job Satisfaction, and Job Performance at Small and Middle-Sized Firms of Taiwan,' Journal of American Academy of Business, 5 $(1 / 2), 432-438$.

Lok, P. \& Crawford, J. (2004). "The Effect of Organizational Culture and Leadership Style on Job Satisfaction and Organizational Commitment," Journal of Management Development, 23(4), 321 - 338.

Lund. D. B. (2003). "Organizational Culture and Job Satisfaction," Journal of Business \& Industrial Marketing, 18(3), 219 - 236.

Meyer, J. P. \& Allen, N. J. (1997). ,Commitment in the Workplace: Theory, Research, and Application,' Thousand Oaks: Sage.

National SME Development Council (NSDC). (2005). Definitions for SME in Malaysia. Bank Negara Malaysia.

National SME Development Council (NSDC), SME Annual Report 2009/10.

O’Dwyer, M., Gilmore, A. \& Carson, D. (2009). "Innovative Marketing in SMEs," European Journal of Marketing, 43(1/2), 46 $-61$.

Oke, A., Burke, G. \& Myers, A. (2007). "Innovation Types and Performance in Growing UK Smes," International Journal of Operation \& Production Management, 27(7), $735-753$. 
O’Regan, N. \& Ghobadian, A. (2004). "Short and Long-Term Performance in Manufacturing SMEs: Different Target, Different Drivers," International Journal of Productivity and Performance Management, 53(5), $405-424$.

Pool, S. \& Pool, B. (2007). "A Management Development Model: Measuring Organizational Commitment and Its Impact on Job Satisfaction among Executives in a Learning Organization," Journal of Management Development, 26(4), 353 369.

Rad, A. M. \& Yarmohammadian, M. H. (2006). "A Study of Relationship between Managers' Leadership Style and Employees' Job Satisfaction," Leadership in Health Sciences, 19(2), Xi - Xxvii.

Rashid, M. Z. A., Sambasivan, M. \& Johari, J. (2003). "The Influence of Corporate Culture and Organizational Commitment on Performance," Journal of Management Development, 22(8), 708-728.

Robbins, S. P. (1996). 'Organizational Behaviour: Concepts, Controversies, and Application (7th Ed.),' Englewood Cliffs, New Jersey: Prentice Hall.

Robbins, S. P. \& Judge, T. A. (2009). 'Organizational Behaviour,' (13th Ed.). New Jersey: Pearson Prentice Hall.

Sadler-Smith, E., Hamson, Y., Chaston, I. \& Badger, B. (2003). "Managerial Behaviour, Entrepreneurial Style, and Small Firm Performance," Journal of Small Business Management, 41(1), 47 - 67.

Sempane, M. E., Rieger, H. S. \& Roodt, G. (2002). "Job Satisfaction in Relation to Organisational Culture," SA Journal of Industrial Psychology, 2002, 28(2), 23-30.

SMEs Prepare For Revival, Growth. Business Times. April 20, 2010. Retrieved April 20, 2010, from http://www.btimes.com.my.
SMI/SME Business Directory. (2008). The Official Business Directory of SMI Association of Malaysia.

Testa, M. R. \& Mueller, S. L. (2009). "Demographic and Cultural Predictors of International Service Worker Job Satisfaction," Managing Service Quality, 19(2), $195-210$.

Verhees, F. J. H. M. \& Meulenberg, M. T. G. (2004). "Market Orientation, Innovativeness, Product Innovation, and Performance in Small Firms," Journal of Small Business Management, 42(2), 134 154.

Wright, T. A. (2006). "The Emergence of Job Satisfaction in Organizational Behaviour: A Historical Overview of the Dawn of Job Attitude Research," Journal of Management History, 12(3), 262 - 277.

Yiing, L. H. \& Ahmad, K. Z. B. (2009). "The Moderating Effects of Organizational Culture on the Relationships between Leadership Behaviour and Organizational Commitment and between Organizational Commitment and Job Satisfaction and Performance," Leadership and Organization Development Journal, 30(1), 53 - 86.

Yousef, D. A. (2001). "Islamic Work Ethic. A Moderator between Organizational Commitment and Job Satisfaction in a Cross-Cultural Context," Personnel Review, 30(2), $152-169$. 